\title{
Tsafon
}

Revue d'études juives du Nord

$72 \mid 2016$

Juifs, Israéliens, dans la littérature française et israélienne

\section{Projet d'un musée à la mémoire des communautés juives disparues dans le monde arabe}

\section{Q OpenEdition}

\section{Journals}

Édition électronique

URL : https://journals.openedition.org/tsafon/465

DOI : $10.4000 /$ tsafon.465

ISSN : 2609-6420

Éditeur

Association Jean-Marie Delmaire

Édition imprimée

Date de publication : 1 décembre 2016

Pagination : 169

ISSN : 1149-6630

Référence électronique

"Projet d'un musée à la mémoire des communautés juives disparues dans le monde arabe », Tsafon

[En ligne], 72 | 2016, mis en ligne le 31 mai 2018, consulté le 24 juin 2021. URL : http://

journals.openedition.org/tsafon/465; DOI : https://doi.org/10.4000/tsafon.465 
Projet d'un musée à la mémoire des communautés juives disparues dans le monde arabe

La publication de notre dossier sur le sort des juifs d'Égypte suite à la guerre du Sinaï, à savoir l'expulsion de la quasi totalité de la population juive d'Égypte, nous a valu plusieurs courriers encourageants, dont un qui nous donne l'information suivante. L'Association mondiale des juifs égyptiens projette la construction, à Jérusalem, d'un musée présentant le «nettoyage ethnique » subi par les communautés juives des pays arabes suite aux diverses guerres israélo-arabes. Ce "nettoyage » a fait environ un million de réfugiés juifs en Israël et par le monde. Ce chiffre est à placer en parallèle au million de réfugiés palestiniens qui revendiquent leur retour en Palestine. Il devrait aussi balayer l'argument de la non responsabilité des pays arabes dans la migration des juifs vers Israël. Si, en effet, les premiers pionniers furent originaires d'Europe, avant même la Shoah et surtout après, de nombreux migrants vers Israël étaient originaires des pays arabes ou moyen-orientaux (Iran par exemple), poussés à l'exil par les gouvernements de leur pays. 